\title{
Association between breakfast omission and abdominal adiposity in low-income adolescents
}

\author{
Associação entre a omissão do desjejum \\ e a adiposidade abdominal em \\ adolescentes de baixa renda
}

\author{
Ana Raquel de Andrade Barbosa RIBEIRO ${ }^{1}$ iD 0000-0001-5780-5676 \\ Danielle Franklin de CARVALHO² ID 0000-0003-4835-082X \\ Anajás da Silva Cardoso CANTALICE ${ }^{4}$ 0000-0002-4709-2294 \\ Mônica Oliveira da Silva SIMÕES2 ID 0000-0002-5803-599X \\ Alessandra TEIXEIRA3 ${ }^{3}$ 0000-0003-1617-6708 \\ Carla Campos Muniz MEDEIROS² ID 0000-0002-7994-7277
}

\section{A B S T R A C T}

\section{Objective}

To assess the association between breakfast omission, overweight/obesity, abdominal adiposity, and unhealthy lifestyle of low-income adolescents.

\footnotetext{
${ }^{1}$ Universidade Federal de Campina Grande, Centro de Ciências Biológicas e da Saúde, Departamento de Medicina. Campina Grande, PB, Brasil.

${ }^{2}$ Universidade Estadual da Paraíba, Centro de Ciências Biológicas e da Saúde, Programa de Pós-Graduação em Saúde Pública. Campina Grande, PB, Brasil. R. Baraúnas, n. 351, Centro de Integração, sala 330, Núcleo de Extensão e Estudos em Pesquisas Epidemiológicas, Bairro Universitário, 58429-500, Campina Grande, PB, Brasil. Correspondence to: C.C.M. MEDEIROS E-mail: <carlamunizmedeiros@hotmail.com>.

3 Universidade Estadual da Paraíba, Grande, Centro de Ciências Biológicas e da Saúde, Departamento de Farmácia. Campina Grande, PB, Brasil.

${ }^{4}$ Universidade Federal de Campina Grande, Centro de Ciências Biológicas e da Saúde, Departamento de Enfermagem. Campina Grande, PB, Brasil.

Article based on the dissertation of A.R.A.B. RIBEIRO, entitled "Relação entre a omissão do desjejum, estado nutricional e estilo de vida em adolescentes escolares". Universidade Estadual da Paraíba; 2019.

Support: Conselho Nacional de Desenvolvimento Científico e Tecnológico (CNPq, National Council for Scientific and Technological Development) (Process n. 481724/2012-5).
}

How to cite this article

Ribeiro ARAB, Carvalho DF, Cantalice ASC, Simões MOS, Teixeira A, Medeiros CCM. Association between breakfast omission and abdominal adiposity in low-income adolescents. Rev Nutr. 2021;34:e190245. https://doi.org/10.1590/1678-9865202134e190245 


\section{Methods}

A cross-sectional population study involving 571 public school students aged between 15 and 19 years old. The habit of having breakfast was assessed using a form, checking the weekly frequency of a given meal and considered as breakfast omission when these adolescents did not have breakfast for at least 5 days in the past week. Sociodemographic and lifestyle variables (sedentarism, physical activity level, and sleep duration) were also assessed. Overweight/obesity was defined as a body mass index above a Z-score of +1 , and the presence of abdominal adiposity was determined by a waist circumference/height ratio greater than 0.5 . The association between breakfast omission and lifestyle variables was assessed using the chi-square test and a multivariate logistic regression of the anthropometric indicators.

\section{Results}

The omission of breakfast was found in $31 \%$ of the adolescents and was associated with physical inactivity $(p<0.001)$. Regarding anthropometric indicators, breakfast omission was an independent factor for determining abdominal adiposity, with a 1.8 times greater chance of having this condition among those who omitted breakfast $(p=0.037)$.

\section{Conclusion}

Omitting breakfast was frequent among the students assessed, and was associated with abdominal adiposity, a cardiometabolic risk factor. Investigation and early intervention are fundamental to change this behavior.

Keywords: Adolescent. Breakfast. Nutritional status. Obesity.

\section{RE S U M O}

\section{Objetivo}

O estudo objetivou avaliar a associação entre omissão do desjejum, sobrepeso/obesidade, adiposidade abdominal e estilo de vida não saudável em adolescentes de baixa renda.

\section{Métodos}

Este foi um estudo populacional com delineamento transversal, envolvendo 571 adolescentes de escolas públicas, entre 15 e 19 anos. O hábito do desjejum foi avaliado através de formulário que verificou a frequência semanal da realização dessa refeição, sendo considerado omissão do desjejum quando os adolescentes não o realizaram por pelo menos cinco dias na última semana. Variáveis sociodemográficas e de estilo de vida (sedentarismo, nível de atividade física e horas de sono) também foram analisadas. A classificação em sobrepeso/obesidade contemplou o índice de massa corporal acima do +1 escore-z, e definiu-se adiposidade abdominal quando a relação circunferência abdominal/estatura foi maior que 0,5. A associação entre a omissão do desjejum e as variáveis de estilo de vida foi avaliada através do teste do qui-quadrado e com os indicadores antropométricos por regressão logística multivariada

\section{Resultados}

O hábito de omitir o desjejum esteve presente em 31\% dos adolescentes e apresentou associação com a inatividade física $(p<0,001)$. Em relação aos indicadores antropométricos, a omissão do desjejum foi um fator independente para determinação da adiposidade abdominal, verificando-se uma chance 1,8 vezes maior de presença dessa condição entre os que omitiam o desjejum ( $p=0,037)$.

\section{Conclusão}

A omissão do desjejum foi frequente entre os estudantes avaliados e esteve associada à adiposidade abdominal, um fator de risco cardiometabólico, sendo fundamental a investigação e a intervenção precoce para a mudança desse comportamento.

Palavras-chave: Adolescente. Desjejum. Estado nutricional. Obesidade.

\section{NTRODUCTION}

Adolescence comprises a phase of sudden changes in which individuals establish the bases for their health throughout adulthood, being so an opportune moment for carrying out interventions [1]. The contemporary lifestyle has contributed to an increasing number of people omitting breakfast and this behavior has been frequent among adolescents [2-4]. 
The omission of breakfast can have repercussions on several aspects of adolescent health, such as cognitive and academic performance, quality of life, well-being, and nutritional status, leading to the emergence of obesity and abdominal adiposity, conditions related to the onset of chronic non-communicable diseases in adulthood [4,5]. While most papers in the literature have assessed the association of the habit of omitting breakfast among young people with the occurrence of overweight/obesity, few assessed the impact of this behavior on abdominal adiposity, especially among Brazilian adolescents in which the scientific literature is still scarce and not conclusive [4-9].

In addition, most existing studies, when assessing this association, do not consider the presence of confounding factors such as lifestyle (physical activity, physical inactivity, and sleep) [4]. Based on these facts, this study aimed to verify the association between breakfast omission, overweight/obesity, abdominal adiposity, and unhealthy lifestyle of low-income adolescents.

\section{METHODS}

A cross-sectional population study, conducted in state high schools between September 2012 and June 2013, in the city of Campina Grande (PR), Brazil. The study population consisted of students, between 15 and 19 years old, enrolled in public institutions in the urban area.

For the sample calculation, it was considered the total number of students enrolled $(9,294$ students distributed in 264 classes), an estimated proportion of 50\%, a sampling error of 5\%, design effect (deff) of 1.5 (correction factor for random sampling by conglomerate) and an increase of $3 \%$ for eventual losses or refusals. The estimated minimum sample, therefore, was 570 students. Considering, as previously verified in the pilot study, the average number of 15 students per class, 39 classes were drawn, distributed in 18 schools. Five hundred eighty-three adolescents were contacted, but there were seven exclusions and five losses due to the non-response to the assessed item. In the end, 571 individuals were assessed.

Anthropometric data were collected in duplicate, being considered the average value of the two measurements. To assess and categorize nutritional status, the Body Mass Index (BMI) was used, following the recommendations of the Ministério da Saúde (Brazilian Ministry of Health) [10]. The Waist-to-Height Ratio (WHtR) was used to characterize abdominal adiposity, being considered present when WHtR was greater than 0.5 [11].

The omission of breakfast was assessed using the same question adopted in the Pesquisa Nacional de Saúde do Escolar (National Adolescent School-based Health Survey) which aims to verify the consumption of healthy and unhealthy foods in the past weeks [3]. Cases of students who did not have breakfast for at least 5 days in the past week were considered as breakfast omissions. The sociodemographic variables assessed were sex, age, social class - according to the criteria of the Associação Brasileira de Empresa de Pesquisa (ABEP, Brazilian Association of Research Companies) - and maternal educational level complete years of schooling [12].

Regarding lifestyle, those who performed less than 300 weekly minutes of accumulated physical activity were considered inactive. Those who slept less than 8 hours a day were classified as having sleep deprivation [3]. Data analysis was performed using the SPSS software, version 22.0 [13]. The Chi-Square test was performed to assess the relationship between breakfast omission and sociodemographic, lifestyle, nutritional status, and abdominal adiposity indicators.

To test the independence of breakfast omission and other factors in determining obesity/overweight and abdominal adiposity in the adolescents, a univariate logistic regression was performed. Subsequently, a multivariate model was constructed using the forward method according to a decreasing Odds Ratio with 
the inclusion of variables that obtained a " $p$ " equal to or less than 0.20 in the univariate analysis. To assess the fit of the model, the Hosmer-Lemeshow test was performed. A 95\% confidence interval was considered for all statistical analyses.

The study was approved by the Comitê de Ética em Pesquisa da Universidade Estadual da Paraiba (Research Ethics Committee of the Paraíba State University), Certificado de Apresentação para Apreciação Ética (CAAE, Presentation Certificate for Ethical Appreciation) (n. 0077.0.133.000-12).

\section{RE S U L T S}

Of the adolescents, $59.8 \%$ were between 15 and 17 years old, $66.5 \%$ were female and $69.4 \%$, who came from the social classes C, D, and E (low-income strata). The omission of breakfast was present in $31 \%$ and was associated physical inactivity $(p<0.001)$, obesity/overweight $(p=0.003)$, and abdominal adiposity $(p=0.027)$ (Table 1).

Table 1 - Distribution of adolescents regarding socio-demographic, lifestyle, and nutritional status variables according to the omission of breakfast. Campina Grande (PB), Brazil, 2013.

\begin{tabular}{|c|c|c|c|c|c|c|c|c|c|}
\hline \multirow{3}{*}{ Variables } & & & \multicolumn{4}{|c|}{ Breakfast omission } & \multirow{3}{*}{$p$-value } & \multirow{3}{*}{ PR } & \multirow{3}{*}{$\mathrm{C} 195 \%$} \\
\hline & \multicolumn{2}{|c|}{ Total $n=571$} & \multicolumn{2}{|c|}{ Yes } & \multicolumn{2}{|c|}{ No } & & & \\
\hline & $\mathrm{n}$ & $\%$ & $n$ & $\%$ & $n$ & $\%$ & & & \\
\hline$\overline{\operatorname{Sex}}$ & & & & & & & 0.167 & 1.31 & $0.89-1.92$ \\
\hline Female & 380 & 66.5 & 125 & 32.9 & 255 & 67.1 & & & \\
\hline Male & 191 & 33.5 & 52 & 27.2 & 139 & 72.8 & & & \\
\hline Age group (years) & & & & & & & 0.459 & 1.14 & $0.79-1.64$ \\
\hline $15-17$ & 342 & 59.9 & 102 & 29.8 & 240 & 70.2 & & & \\
\hline $18-19$ & 229 & 40.1 & 75 & 32.8 & 154 & 67.2 & & & \\
\hline Social class & & & & & & & 0.128 & 1.34 & $0.91-1.95$ \\
\hline$C, D$, and $E$ & 396 & 69.4 & 115 & 29.9 & 281 & 71.1 & & & \\
\hline$A, B$ & 175 & 30.6 & 62 & 35.4 & 113 & 64.6 & & & \\
\hline $\begin{array}{l}\text { Maternal educational level } \\
\text { (years of schooling)* }\end{array}$ & & & & & & & 0.738 & 0.94 & $0.65-1.35$ \\
\hline $0-8$ & 328 & 58.2 & 103 & 31.4 & 225 & 68.6 & & & \\
\hline$>8$ & 236 & 41.8 & 71 & 30.1 & 165 & 69.9 & & & \\
\hline Physical activity (minutes/week) & & & & & & & $<0.001$ & 2.11 & $1.44-3.10$ \\
\hline$<300$ & 342 & 59.9 & 127 & 37.1 & 215 & 62.9 & & & \\
\hline$\geq 300$ & 229 & 40.1 & 50 & 21.8 & 179 & 78.5 & & & \\
\hline Sedentary time (hours/day) & & & & & & & 0.347 & 0.83 & $0.56-1.22$ \\
\hline$\geq 2$ & 381 & 66.7 & 54 & 28.4 & 136 & 71.6 & & & \\
\hline$<2$ & 190 & 33.3 & 123 & 32.3 & 258 & 67.7 & & & \\
\hline Hours of sleep (hours/day) & & & & & & & 0.081 & 1.91 & $1.23-2.97$ \\
\hline$<8$ & 422 & 73.9 & 32 & 21.5 & 117 & 78.5 & & & \\
\hline$\geq 8$ & 149 & 26.1 & 145 & 34.4 & 277 & 65.6 & & & \\
\hline Nutritional status & & & & & & & 0.003 & 1.49 & $0.95-2.31$ \\
\hline Overweight/obesity & 102 & 17.9 & 39 & 38.2 & 63 & 61.8 & & & \\
\hline Eutrophic/low weight & 469 & 82.1 & 138 & 29.4 & 331 & 70.6 & & & \\
\hline Waist-to-Height Ratio & & & & & & & 0.027 & 1.86 & $1.06-3.24$ \\
\hline$>0.5$ & 57 & 10.0 & 152 & 29.6 & 362 & 70.4 & & & \\
\hline$\leq 0.5$ & 514 & 90.0 & 25 & 43.9 & 32 & 56.1 & & & \\
\hline
\end{tabular}

Note: "Seven were unwilling or unable to answer; Cl: Confidence Interval; PR: Prevalence Ratio. 
Breakfast omission was an independent factor for abdominal adiposity PR:1.81 (95\% Cl: 1.04-3.17), ( $p=0.037$ ) (Table 2). Social classes A and B also were an independent factor for obesity/overweight PR: 1.73 (95\%Cl: 1.11-2.70), $(p=0.037)$ (Table 3).

Table 2 - Abdominal adiposity according to sociodemographic, lifestyle, and breakfast omission variables in adolescents. Campina Grande (PB), Brazil, 2013.

\begin{tabular}{|c|c|c|c|c|c|c|c|c|}
\hline \multirow{3}{*}{ Variables } & \multicolumn{4}{|c|}{ Abdominal adiposity } & \multirow{3}{*}{$\begin{array}{c}\begin{array}{c}\text { Univariate } \\
\text { analysis }\end{array} \\
\text { PR }(95 \% \mathrm{Cl})\end{array}$} & \multirow{3}{*}{$p$-value } & \multirow{3}{*}{$\begin{array}{c}\begin{array}{c}\text { *Multivariate } \\
\text { analysis }\end{array} \\
\text { PR }(95 \% \mathrm{Cl})\end{array}$} & \multirow{3}{*}{$p$-value } \\
\hline & \multicolumn{2}{|c|}{ Yes } & \multicolumn{2}{|c|}{ No } & & & & \\
\hline & $\mathrm{n}$ & $\%$ & $n$ & $\%$ & & & & \\
\hline \multicolumn{9}{|l|}{ Sex } \\
\hline Female & 18 & 9.4 & 173 & 90.6 & 1 & 0.752 & & \\
\hline Male & 39 & 10.3 & 341 & 89.7 & $1.10(0.61-1.98)$ & & & \\
\hline \multicolumn{9}{|c|}{ Age group (years) } \\
\hline $15-17$ & 31 & 9.1 & 311 & 90.9 & 1 & 0.372 & & \\
\hline $18-19$ & 26 & 11.4 & 203 & 88.6 & $1.29(0.74-2.23)$ & & & \\
\hline \multicolumn{9}{|c|}{$\begin{array}{l}\text { Maternal educational level } \\
\text { (years of schooling) })^{* *}\end{array}$} \\
\hline $0-8$ & 24 & 10.1 & 212 & 89.9 & 1 & 0.966 & & \\
\hline$>8$ & 33 & 10.2 & 293 & 89.8 & $1.01(0.58-1.76)$ & & & \\
\hline \multicolumn{9}{|l|}{ Social class } \\
\hline$C, D$, and $E$ & 34 & 8.6 & 362 & 91.4 & 1 & 0.096 & 1 & 0.127 \\
\hline$A, B$ & 23 & 13.1 & 152 & 86.9 & $1.61(0.92-2.83)$ & & $1.55(0.33-2.73)$ & \\
\hline \multicolumn{9}{|c|}{ Breakfast Omission } \\
\hline No & 25 & 8.1 & 362 & 91.9 & 1 & 0.029 & 1 & 0.037 \\
\hline Yes & 32 & 14.1 & 152 & 85.9 & $1.86(1.07-3.25)$ & & $1.81(1.04-3.17)$ & \\
\hline \multicolumn{9}{|c|}{ Sedentary time (hours/day) } \\
\hline$\geq 2$ & 344 & 90.3 & 37 & 10.7 & 1 & 0.760 & & \\
\hline$<2$ & 170 & 89.5 & 20 & 10.5 & $1.09(0.62-1.96)$ & & & \\
\hline \multicolumn{9}{|c|}{ Physical activity (minutes/week) } \\
\hline$<300$ & 24 & 10.5 & 205 & 89.5 & 1 & 0.745 & & \\
\hline$\geq 300$ & 33 & 9.6 & 309 & 90.4 & $1.10(0.63-1.91)$ & & & \\
\hline \multicolumn{9}{|c|}{ Hours of sleep (hours/day) } \\
\hline$<8$ & 133 & 89.3 & 16 & 10.7 & 1 & 0.720 & & \\
\hline$\geq 8$ & 381 & 90.3 & 41 & 9.7 & $0.90(0.49-1.65)$ & & & \\
\hline
\end{tabular}

Note: "Hosmer-Lemeshow Test $p=1.00 ;{ }^{* *}$ Seven were unwilling or unable to answer; 1 : Group considered as a reference for comparison and calculation of PR. Cl: Confidence Interval; PR: Prevalence Ratio.

Table 3 - Obesity/overweight according to sociodemographic, lifestyle, and breakfast omission variables in adolescents. Campina Grande (PB), Brazil, 2013.

\begin{tabular}{|c|c|c|c|c|c|c|c|c|}
\hline \multirow{3}{*}{ Variables } & \multicolumn{4}{|c|}{ Overweight/obesity } & \multirow{3}{*}{$\begin{array}{l}\text { Univariate analysis } \\
\text { PR (C195\%) }\end{array}$} & \multirow{3}{*}{$p$-value } & \multirow{3}{*}{$\begin{array}{c}\text { *Multivariate } \\
\text { analysis }\end{array}$} & \multirow{3}{*}{$p$-value } \\
\hline & \multicolumn{2}{|c|}{ Yes } & \multicolumn{2}{|c|}{ No } & & & & \\
\hline & $\mathrm{n}$ & $\%$ & $\mathrm{n}$ & $\%$ & & & & \\
\hline \multicolumn{9}{|l|}{ Sex } \\
\hline Female & 32 & 16.8 & 159 & 83.2 & 1 & 0.624 & & \\
\hline Male & 70 & 18.4 & 310 & 81.6 & $1.12(0.71-1.78)$ & & & \\
\hline \multicolumn{9}{|c|}{ Age group (years) } \\
\hline $15-17$ & 64 & 18.7 & 278 & 81.3 & 1 & 0.571 & & \\
\hline $18-19$ & 38 & 16.6 & 191 & 83.4 & $0.86(0.56-1.34)$ & & & \\
\hline
\end{tabular}


Table 3 - Obesity/overweight according to sociodemographic, lifestyle, and breakfast omission variables in adolescents. Campina Grande (PB), Brazil, 2013.

\begin{tabular}{|c|c|c|c|c|c|c|c|c|}
\hline \multirow{3}{*}{ Variables } & \multicolumn{4}{|c|}{ Overweight/obesity } & \multirow{3}{*}{$\begin{array}{l}\text { Univariate analysis } \\
\text { PR (C195\%) }\end{array}$} & \multirow{3}{*}{$p$-value } & \multirow{3}{*}{$\begin{array}{c}{ }^{*} \begin{array}{c}\text { Multivariate } \\
\text { analysis }\end{array} \\
\text { PR (CI95\%) }\end{array}$} & \multirow{3}{*}{$p$-value } \\
\hline & \multicolumn{2}{|c|}{ Yes } & \multicolumn{2}{|c|}{ No } & & & & \\
\hline & $\mathrm{n}$ & $\%$ & $n$ & $\%$ & & & & \\
\hline \multicolumn{9}{|c|}{$\begin{array}{l}\text { Maternal educational level } \\
\text { (years of schooling) }^{* \star}\end{array}$} \\
\hline $0-8$ & 60 & 18.3 & 268 & 81.7 & 1 & 0.779 & & \\
\hline$>8$ & 41 & 17.4 & 195 & 82.6 & $0.94(0.61-1.46)$ & & & \\
\hline \multicolumn{9}{|l|}{ Social class } \\
\hline$C, D$, and $E$ & 60 & 15.2 & 336 & 84.8 & 1 & 0.012 & 1 & 0.015 \\
\hline$A, B$ & 42 & 24.0 & 133 & 76.0 & $1.72(1.14-2.75)$ & & $1.73(1.11-2.70)$ & \\
\hline \multicolumn{9}{|c|}{ Breakfast omission } \\
\hline No & 63 & 16.0 & 331 & 84.0 & 1 & 0.082 & 1 & 0.144 \\
\hline Yes & 39 & 22.0 & 138 & 78.0 & $1.49(0.95-2.32)$ & & $1.44(0.92-2.25)$ & \\
\hline \multicolumn{9}{|c|}{ Sedentary time (hours/day) } \\
\hline$\geq 2$ & 70 & 18.4 & 311 & 81.6 & 1 & 0.653 & & \\
\hline$<2$ & 32 & 16.8 & 158 & 83.2 & $0.90(0.57-1.43)$ & & & \\
\hline \multicolumn{9}{|c|}{ Physical activity (minutes/week) } \\
\hline$<300$ & 41 & 17.9 & 188 & 82.1 & 1 & 0.983 & & \\
\hline$\geq 300$ & 61 & 17.8 & 281 & 82.2 & $0.90(0.64-1.54)$ & & & \\
\hline \multicolumn{9}{|c|}{ Hours of sleep (hours/day) } \\
\hline$<8$ & 29 & 19.5 & 120 & 80.5 & 1 & 0.553 & & \\
\hline$\geq 8$ & 72 & 17.3 & 346 & 82.7 & $0.87(0.54-1.40)$ & & & \\
\hline
\end{tabular}

Note: ${ }^{*}$ Hosmer-Lemeshow Test $p=0.804 ;{ }^{* *}$ Seven were unwilling or unable to answer; 1 : Group considered as a reference for comparison and calculation of PR; Cl: Confidence Interval; PR: Prevalence Ratio.

\section{DISCUSSION}

The results of this study reinforce the hypothesis that the omission of breakfast represents an independent factor for the presence of abdominal adiposity in low-income adolescents. In turn, this is considered an indicator of the presence of metabolic alterations, such as insulin resistance, and is included as part of the criteria for diagnosis of metabolic syndrome [14].

The prevalence of breakfast omission observed in this study was lower than that verified in the ERICA Study involving 74,589 students from 1,247 educational institutions, distributed in 124 Brazilian cities, being $45.3 \%$ in the Northeastern region of Brazil [2]. A systematic review involving 286,804 children and adolescents from different continents (Europe, North America, Oceania, Asia, and Africa) also found a wide variability in the prevalence of this behavior among the studies assessed (0.7\% to $74.7 \%)$ [4]. This difference may be due to the type of population assessed and the variation in the criteria adopted to define the omission of breakfast.

The habit of omitting breakfast tends to be more present in adolescents than in children, in girls, and in those whose mothers have a lower educational level and purchasing power $[2,4,15]$. In the present study, however, there was no association between the habit of omitting breakfast and the socio-demographic variables assessed.

Studies point out that adolescents who omit breakfast also present other unhealthy lifestyle indicators $[4,16]$. In the present study, it was verified that those who did not have the habit of having breakfast had 
a greater chance of being inactive. Something similar was found in a study of British adolescents aged between 10 and 16 years old [17].

A Spanish study with more than 3,000 adolescent students showed that, although there is an association between obesity and physical inactivity, and between obesity and breakfast omission, there was no significant relationship between breakfast omission and physical inactivity [18]. This was also observed in the study entitled Healthy Lifestyle in Europe by Nutrition in Adolescence (HELENA), which involved 2,148 adolescents aged between 12.5 and 17.5 years old and residents of 10 European cities, in which breakfast was not associated with either sedentary time or physical activity [19].

In the present study, obesity/overweight as well as abdominal adiposity were more prevalent in those who omitted breakfast, but only abdominal adiposity was independently associated to the habit of omitting breakfast. The association between breakfast omission and overweight/obesity was found in 270,362 in of children and adolescents assessed (94.7\%) through a systematic review study, however it is important to emphasize that most studies did not make adjustments for confounding factors such as sex, age, and lifestyle [4].

A meta-analysis involving 16 observational studies stated that the risk of overweight and obesity in children and adolescents who did not have breakfast was 43\% higher than those who regularly did [9]. Some mechanisms have been proposed to explain this association: greater thermogenesis among those who have breakfast, and decreased satiety among those who do not have [9].

In this study, adolescents who omitted breakfast were 1.8 times more likely to have abdominal adiposity when compared to those who did not omit breakfast. Similar data were found in studies involving Australian and Iranian children and adolescents. The first one involved 3,884 individuals aged between 5 and 16 years old and verified a 1.7 times greater chance of presenting abdominal adiposity among those who omitted breakfast [20]. In the Iranian study, that involved 5,625 students aged between 10 and 18 years old, the chance of abdominal adiposity among those who omitted breakfast was a little lower, 1.4 times [8].

Abdominal adiposity, regardless of the presence or absence of nutritional state alterations, is more closely related to cardiometabolic complications in adolescence and to breakfast omission [21]. It is important to emphasize that this last condition can also be associated to the reduction of insulin sensitivity, since the ingestion of this meal has a beneficial effect on appetite regulation and also improves the glycemic response at the next meal, by providing an increase in insulin sensitivity $[22,23]$.

One of the limitations of the study is the diversity of the concept of "breakfast omission", making it difficult to compare studies. In addition, factors regarding eating habits that can influence obesity risk, such as time to eat breakfast, the meal composition, the habit of eating or omitting other meals, as well as eating patterns, were not assessed in this study. It is also important to emphasize the limitations related to cross-sectional designs, and that it is not possible to establish a causal relationship between the omission of breakfast and the variables studied.

\section{CONCLUSION}

Omission of breakfast was frequent among the students assessed and was associated with abdominal adiposity, which is considered an indicator of cardiovascular risk. The early identification and intervention to change this behavior can contribute to minimize the impact of chronic non-communicable diseases not only in the individual context but also in the collective. 
ARAB RIBEIRO, DF CARVALHO, and CCM MEDEIROS contributed with conception, design, data analysis and interpretation, and review and approval of the final version of the article. ASC CANTALICE contributed with review and approval of the final version of the article. MOS SIMÕES and A TEIXEIRA contributed with the approval of the final version of the article.

\section{REFERENCES}

1. Zalewska M, Maciorkowska E. Selected nutritional habits of teenagers associated with overweight and obesity. Peer J. 2017;5:e3681. https://doi.org/10.7717/peerj.3681

2. Barufaldi LA, Abreu GZ, Oliveira JS, Santos DF, Fujimori E, Vasconcelos SML, et al. ERICA: Prevalência de comportamentos alimentares saudáveis em adolescentes brasileiros. Rev Saúde Pública. 2016;50(Suppl1):6s. https://doi. org/10.1590/s01518-8787.2016050006678

3. Instituto Brasileiro de Geografia e Estatística. Pesquisa Nacional de Saúde do Escolar 2015. Rio de Janeiro: Instituto; 2016.

4. Lundqvist $M$, Vogel NE, Levin LÅ. Effects of eating breakfast on children and adolescents: a systematic review of potentially relevant outcomes in economic evaluations. Food Nutr Res. 2019;63. http://doi.org/10.29219/fnr. v63.1618

5. Monzani A, Ricotti R, Caputo M, Solito A, Archero F, Bellone S, et al. A systematic review of the association of skipping breakfast with weight and cardiometabolic risk factors in children and adolescents: what should we better investigate in the future? Nutrients. 2019;11(2):387. https://doi.org/10.3390/nu11020387

6. Fiuza RFP, Muraro AP, Rodigures PRM, Sena EMS, Ferreira MG. Omissão do desjejum e fatores associados entre adolescentes brasileiros. Rev Nutr. 2017;30(5):615-626. https://doi.org/10.1590/1678-98652017000500007

7. Hassan BK, Cunha DB, Veiga GV, Pereira RA, Hoffman DJ, Sichieri R. Breakfast consumption, family breakfast, and adiposity trajectory in adolescence: the adolescent nutritional assessment longitudinal cohort study. J Acad Nutr Diet. 2019;119(6):944-56. https://doi.org/10.1016/j.jand.2018.11.014

8. Ghafari M, Doosti-Irani A, Amiri M, Cheraghi Z. Prevalence of the skipping breakfast among the iranian students: a review article. Iran J Public Health. 2017;46(7):882-9.

9. Ardeshirlarijani E, Namazi N, Jabbari M, Zeinali M, Gerami H, Jalili RB, et al. The link between breakfast skipping and overweigh/obesity in children and adolescents: a meta-analysis of observational studies. J Diabetes Metab Disord. 2019;18(2):657-64. https://doi.org/10.1007/s40200-019-00446-7

10. Ministério da Saúde (Brasil). Orientações para a coleta e análise de dados antropométricos em serviços de saúde: norma técnica do Sistema de Vigilância Alimentar e Nutricional SISVAN. 4a. ed. Brasília: Ministério 2011.

11. Kuba VM, Leone C, Damiani D. Is waist-to-height ratio a useful indicator of cardio-metabolic risk in 6-10-year-old children? Bmc Pediatr. 2013;13:91. https://doi.org/10.1186/1471-2431-13-91

12. Associação Brasileira de Empresas de Pesquisa. Dados com base no Levantamento Sócio Econômico 2010 IBOPE. São Paulo: Associação; 2011 [citado 14 jun 2012]. Disponível em: http://www.abep.org/new/

13. International Business Machines Corporation. SPSS Statistics for Windows. version 22.0. Released 2013. Armonk: IBM; 2013.

14. He F, Rodriguez-Colon S, Fernandez-Mendoza J, Vgontzas AN, Bixler EO, Berg A, et al. Abdominal obesity and metabolic syndrome burden in adolescents: Penn State Children Cohort Study. J Clin Densitom. 2015;18(1):30-6. https://doi.org/10.1016/j.jocd.2014.07.009

15. Frayon S, Cherrier S, Cavaloc Y, Touitou A, Zongo P, Wattelez G, et al. Nutrition behaviors and sociodemographic factors associated with overweight in the multi-ethnic adolescents of New Caledonia. Ethn Health. 2019;24(2):194-210. https://doi.org/10.1080/13557858.2017.1315530

16. Blondin SA, Anzman-Frasca S, Djang HC, Economos CD. Breakfast consumption and adiposity among children and adolescents: an updated review of the literature. Pediatr Obes. 2016;11(5):333-48. https://doi.org/10.1111/ ijpo.12082 
17. Sandercock GR, Voss C, Dye L. Associations between habitual school-day breakfast consumption, body mass index, physical activity and cardiorespiratory fitness in English schoolchildren. Eur J Clin Nutr. 2010;64(10):1086-92. https:// doi.org/10.1038/ejcn.2010.145

18. Garcia-Continente X, Allué N, Pérez-Giménez A, Ariza C, Sánchez-Martínez F, López MJ, et al. Hábitos alimentarios, conductas sedentarias y sobrepeso y obesidad en adolescentes de Barcelona. An Pediatr. 2015;83(1):3-10. https:// doi.org/10.1016/j.anpedi.2014.07.006

19. Cuenca-García M, Ruiz JR, Ortega FB, Labayen I, González-Gross M, Moreno LA, et al. Association of breakfast consumption with objectively measured and self-reported physical activity, sedentary time and physical fitness in European adolescents: the HELENA (Healthy Lifestyle in Europe by Nutrition in Adolescence) study. Public Health Nutr. 2014;17(10):2226-36. https://doi.org/10.1017/\$1368980013002437

20. Mihrshahi S, Drayton BA, Bauman AE, Hardy LL. Associations between childhood overweight, obesity, abdominal obesity and obesogenic behaviors and practices in Australian homes. Bmc Public Health. 2017;18(1):44. https://doi. org/10.1186/s12889-017-4595-y

21. El-Kassas G, Ziade F. Exploration of the risk factors of generalized and central obesity among adolescents in North Lebanon. J Environ Public Health. 2017;2017:2879075. https://doi.org/10.1155/2017/2879075

22. Jarvandi S, Schootman M, Racette SB. Breakfast intake among adults with type 2 diabetes: influence on daily energy intake. Public Health Nutr. 2015;18(12):2146-52. https://doi.org/10.1017/S1368980014002973

23. Chen $H$, Zhang B, Ge Y, Shi H, Song S, Xue W, et al. Association between skipping breakfast and risk of cardiovascular disease and all cause mortality: a meta-analysis. Clin Nutr. 2020;17:S0261-5614(20)30052-2. https:// doi.org/10.1016/j.clnu.2020.02.004 